\title{
A Case of CIDP Concurrent With MGUS IgG Kappa Responsive to Autologous Stem Cell Transplantation
}

Neurol Neuroimmunol Neuroinflamm 2021;8:e995. doi:10.1212/NXI.0000000000000995

In the Clinical/Scientific Note "A case of CIDP concurrent with MGUS IgG kappa responsive to autologous stem cell transplantation" by Colucci et al, ${ }^{1}$ the legend of figure 1 should include the $\boldsymbol{\ell}$ symbol before "preventive hematopoietic stem cell mobilization and collection." The publisher regrets the error.

Further, the final sentence of the Discussion section should read, "Our report may as well suggest investigating other novel myeloma-specific therapeutic approaches in clinically refractory CIDP with concurrent MGUS, e.g., the anti-CD38 antibody daratumumab and venetoclax, a selective, orally bioavailable B-cell lymphoma 2 (BCL-2) inhibitor that induces cell death in multiple myeloma cells, particularly in those harboring $t(11 ; 14)$, that express high levels of BCL-2 relative to BCL-extra large (BCL-XL) and myeloid cell leukemia 1 (MCL-1).” The authors regret the error.

\section{Reference}

1. Colucci G, Pabst T, Bacher U, et al. A case of CIDP concurrent with MGUS IgG kappa responsive to autologous stem cell transplantation. Neurol Neuroimmunol Neuroinflamm 2020;7:e888. doi: 10.1212/NXI.0000000000000888. 


\section{Neurology \\ Neuroimmunology \& Neuroinflammation}

\section{A Case of CIDP Concurrent With MGUS IgG Kappa Responsive to Autologous Stem Cell Transplantation \\ Neurol Neuroimmunol Neuroinflamm 2021;8; \\ DOI 10.1212/NXI.0000000000000995}

This information is current as of March 26, 2021

Updated Information \&

Services

References

Permissions \& Licensing

Reprints including high resolution figures, can be found at:

http://nn.neurology.org/content/8/3/e995.full.html

This article cites 1 articles, 1 of which you can access for free at: http://nn.neurology.org/content/8/3/e995.full.html\#\#ref-list-1

Information about reproducing this article in parts (figures,tables) or in its entirety can be found online at:

http://nn.neurology.org/misc/about.xhtml\#permissions

Information about ordering reprints can be found online: http://nn.neurology.org/misc/addir.xhtml\#reprintsus

Neurol Neuroimmunol Neuroinflamm is an official journal of the American Academy of Neurology.

Published since April 2014, it is an open-access, online-only, continuous publication journal. Copyright $\odot$ 2021 American Academy of Neurology. All rights reserved. Online ISSN: 2332-7812.

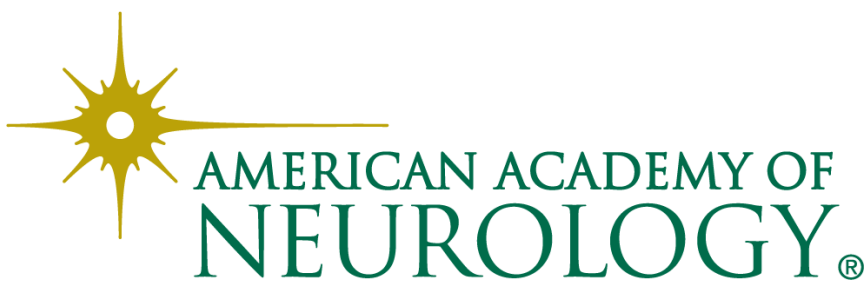

